\title{
Sheltering in place swings door open wide to food insecurity during COVID-19 pandemic
}

\author{
Amir Alakaam*1, Sondra Gudmundson² \\ ${ }^{1}$ Department of Health and Human Performance, University of Tennessee at Chattanooga, Chattanooga, Tennessee, United \\ States \\ ${ }^{2}$ Department of Psychology, Bemidji State University, Bemidji, Minnesota, United States
}

Received: September 18, 2020

DOI: $10.5430 / \mathrm{cns} . \mathrm{v} 9 \mathrm{n} 1 \mathrm{p} 11$
Accepted: October 16, 2020

Online Published: October 23, 2020

\begin{abstract}
The COVID-19 pandemic is causing economic devastation and health system instability around the world. It has been reported that virus pandemics result in food crises even before the appearance of health impacts of the virus in the community. Addressing the consequences of food insecurity is critical during public health crises such as the COVID-19 pandemic. Currently, there is no evidence for the best module or practice used to reduce food insecurity during COVID-19 pandemic. However, a previously adapted tool can be used to address and measure community needs as well as expand access to food. The purpose of this report is to introduce the impact of the COVID-19 pandemic on food insecurity among the low-income population of the United States and to provide a suggestion to intervene on the impact. Using a validated tool to identify food insecurity, coupled with urgent immediate policy change, may diminish consequences of food insecurity and protect the health of those most fragile during a pandemic crisis in rural and low-income communities.
\end{abstract}

Key Words: Nutrition, COVID-19, Rural, Public health, Prevention

\section{INTRODUCTION}

Food insecurity is defined as a limited access to adequate food and nutrition resources to satisfy the dietary needs of individuals. ${ }^{[1,2]}$ It occurs due to unavailability of nutritionally acceptable food or financial limitations in the ability of accessing food. ${ }^{[1,2]}$ Given the geographic diversity and variation in COVID-19 prevalence in the United States, ${ }^{[3]}$ and the extensive measures to reduce person-to-person transmission of the virus that have been applied to control the pandemic, ${ }^{[4]}$ food access and availability will be highly impacted. Solutions for feeding low-income and rural communities will need to be tailored to reduce stigma towards individuals for receiving nutritious food. The purpose of this report is to introduce the impact of the COVID-19 pandemic on food insecurity among low-income population in the United States and to provide a suggestion for using a developed tool to measure the impact and thereby serving to guide researchers and health care providers on the issue.

The COVID-19 pandemic is one of the largest outbreaks in human history, and it is impacting the global population in radical ways. ${ }^{[3,5]}$ It is causing economic devastation around the world. The outbreak of the novel coronavirus was first reported in Wuhan, China, on 31 December, 2019, ${ }^{[5]}$ and it then spread to include more than seven million cases in the United States as of October 13, 2020. ${ }^{[3]}$ To control the spread of the virus, United States officials and local governments

\footnotetext{
* Correspondence: Amir Alakaam; Email: amir-alakaam@utc.edu; Address: Department of Health and Human Performance, University of Tennessee at Chattanooga, 518 Oak Street, Dept 6606, Chattanooga, TN 37403, United States.
} 
implemented several strict measures to prevent person-toperson transmission and to control the spread of COVID19. Such measures include shelter-in-place orders, travel restrictions, social distancing, school closures, limited dining service, no on-site food consumption, prioritizing medical resources, and many others. ${ }^{[4,6]}$ These measures directly and indirectly impact individuals' access to food in many areas in the United States and amongst several communities.

Food insecurity has been reported among the US population in several studies and reports. ${ }^{[1,2,7,8]}$ In 2019, approximately thirteen million households in the United States were food insecure at some time during the year. ${ }^{[8]}$ Moreover, about $14 \%$ of households with children and $35 \%$ of households with incomes below the poverty line were food insecure in 2019. ${ }^{[8]}$ Food insecurity negatively and independently impacts health status, chronic disease outcome, nutritional intake, and daily physical performance. Research indicates food insecure individuals experience significant limitations in activities of daily living and lower nutrient intake, as well as increased susceptibility to poor health status and depression. ${ }^{[2,9]}$ It has been reported that virus pandemics result in food crises even before the appearance of health problems of the virus in the community. ${ }^{[1]}$ Addressing the consequences of food insecurity is critical during public health crises such as the COVID-19 pandemic. Such consequences may include limited food intake, widespread malnutrition, reduced household food supply, decreased quality of life, health disparities, increased risk of chronic disease, and functional impairments. ${ }^{[1,10,11]}$

Food crises and economic struggle can have a significant influence on the consumption of a nutritious diet specifically among food and nutrition assistance program participants. In most cases, those participants receive about half of their daily intake from food assistance programs such as Supplemental Nutrition Assistance Program (SNAP), National School Lunch Program (NSLP), School Breakfast Program (SBP), or Women, Infant \& Children Program (WIC). ${ }^{[1,12,13]} \mathrm{Sev}$ eral states' governments ordered schools to close due to the COVID-19 pandemic. School closures may be necessary to reduce virus transmission but will decrease food intake among low-income children. Schools may be the only consistent place where some children are exposed to fruits and vegetables or receive a nutritious meal in rural areas.

Children who qualify for free and reduced-price meals in school come from low-income households and consume over half of their daily calories at school. ${ }^{[13]}$ Low-income children during the COVID-19 pandemic may experience iron deficiency, low bone density, behavioral problems, depression, anxiety, dental caries, asthma, frequent colds, and poor educational performance due to food insecurity at home. ${ }^{[11,14]}$

\section{INTERVENTION TO ADDRESS FOOD INSE- CURITY}

While many health programs and organizations have made progress in improving hunger incidence, continued effort is still required at all levels especially during a pandemic. Currently, there is no evidence for the best module or practice to use to reduce food insecurity during the COVID-19 pandemic; however, a previously adapted tool can be used to address and measure community needs, as well as expand access to food.

Healthcare and nutrition providers must recognize the most current impactful resources to use in their practice and among their community members. Multiple validated tools to measure food insecurity have been used in different settings during an outbreak. The Household Food Insecurity Access Scale, the Radimer/Cornell hunger scale, and Prioritizing Food Security Solutions (FSS) are some of the tools that have been used in health crises such as the human HIV epidemic, Ebola outbreak, influenza virus pandemic, and widespread malnutrition in children. ${ }^{[15-17]}$ These tools usually share the same concept of early predictions of food insecurity through a survey and then summarize the finding in a scale to prioritize the needs and identify a solution.

Health care providers and researchers can use the FSS tool during the COVID-19 pandemic. This tool is a four-step prioritizing process that can be used to identify and improve food insecurity in the US rural areas and among low-income communities. ${ }^{[17]}$ Step 1 of this process identifies and analyzes the current food security challenges and needs in the community. Step 2 creates five to ten solutions to address the identified needs. Solutions can develop a new program or modify an existing one. Step 3 estimates costs and benefits and creates an impact score of each solution. Step 4 is the final step in which solutions will be ranked and prioritized, and a decision will be made to pursue one solution or more over a few weeks. ${ }^{[17]}$

The Prioritizing Food Security Solutions tool was developed and validated by team of experts and based on community input. ${ }^{[18]}$ It has been also field-tested in several communities and can be adapted within the United States and in other countries. ${ }^{[17,18]}$ When applying the FSS outside of the United States, some of the indicators, program categories, impact criteria, and the weights of those criteria need to be adjusted. ${ }^{[18]}$ What makes FSS applicable to use for the COVID-19 pandemic is that it has been designed to measure food insecurity in areas where there are outdated statistics, unpredictable scenarios, or unspecific data to a regional area. ${ }^{[17]}$ Like in the case of the COVID-19 pandemic, data can change every day. ${ }^{[3]}$ 
Although food insecurity can be measured and addressed by a tool, it is important to recognize that a short-term policy or initiative modification may help to prevent food insecurity in low-income communities resulting from loss of access to meals provided by nutrition assistant programs. ${ }^{[19]}$ The following suggestions can be adapted to reduce food insecurity and to ensure individuals have enough food to eat in the United States:

1) Federal and regional food assistance programs should be provided to rural individuals to prevent further adverse consequences in nutritional and health status. ${ }^{[19]}$

2) Improve benefits of SNAP and WIC programs during the pandemic not just by increasing funding, but by expanding eligibility criteria, providing multiple days meals, and allowing drive-through meal pickup. ${ }^{[19]}$

3) Continual operations of school nutrition programs are imperative for children, therefore the Healthy, Hunger-Free Kids Act needs to be modified to assure SBP and NSLP are efficiently implemented and funding is secure even during school closures. ${ }^{[20]}$

4) Federal nutrition assistant programs should also include food packages that are ready to use such as Ready-to-Use
Therapeutic Food (RUTF). ${ }^{[19,21]}$ This food does not require refrigeration, has a long shelf life (up to 2 years), and is ready to consume without preparation. It has been effective in preventing malnutrition especially among vulnerable populations like children and the elderly during a pandemic. ${ }^{[21,22]}$

5) Federal government should include provisions in any Economic Impact Payments or stimulus package that ensures all individuals have access to adequate food. ${ }^{[23]}$

While there are many unanswered questions relating to the long-term impact of the COVID-19 pandemic on vulnerable populations, there is no doubt that lack of access to food increases the probability of nutritional-related conditions and pervasiveness of food insecurity. Proactive measures by healthcare professionals to introduce the use of a validated tools in rural geographical margins to identify food insecurity, coupled with urgent immediate policy shaping to intervene, may be able to diminish consequences of food insecurity in rural and low-income communities while serving to protect the nutritional health of those most fragile during a pandemic crisis.

\section{Conflicts of InTEREST Disclosure}

The authors declare they have no conflicts of interest.

\section{REFERENCES}

[1] United States Agency for International Development. Leadership During a Pandemic: What Your Municipality Can Do. Available from: https: //www.hsdl.org/?abstract\&did=750946

[2] Nazmi A, Martinez S, Byrd A, et al. A systematic review of food insecurity among US students in higher education. Journal of Hunger \& Environmental Nutrition. 2019; 14(5): 725-740. https : //doi.org/10.1080/19320248.2018.1484316

[3] Centers for Disease Control and Prevention. Cases of Coronavirus Disease (COVID-19) in the U.S. Available from: https://www.cdc.gov/coronavirus/2019-ncov/cases-u pdates/cases-in-us.html

[4] The White House. Executive Orders. Available from: https://www. whitehouse.gov/presidential-actions /executive-order-prioritizing-allocating-health-m edical-resources-respond-spread-covid-19/

[5] World Health Organization. Coronavirus disease (COVID-19) pandemic. Available from: https://www.who.int/emergencies/ diseases/novel-coronavirus-2019

[6] Centers for Disease Control and Prevention. Coronavirus Disease 2019 (COVID-19). Available from: https://www.cdc.gov/coronavirus/2019-ncov/prev ent-getting-sick/social-distancing.html

[7] Wight V, Kaushal N, Waldfogel J, et al. Understanding the link between poverty and food insecurity among children: Does the definition of poverty matter? Journal of Children and Poverty. 2014; 20(1): 1-20. PMid: 25045244. https ://doi.org/10.1080/1079 6126.2014 .891973
[8] United States Department of Agriculture. Food Security in the U.S. Available from: https://www.ers.usda.gov/topics/food-n utrition-assistance/food-security-in-the-us/key-s tatistics-graphics/\#foodsecure

[9] Golovaty I, Tien PC, Price JC, et al. Food insecurity may be an independent risk factor associated with nonalcoholic fatty liver disease among low-income adults in the united states. J Nutr. 2020; 150(1): 91-98. PMid: 31504710. https://doi.org/10.1093/jn/nxz21 2

[10] Jackson JA, Branscum A, Tang A, et al. Food insecurity and physical functioning limitations among older US adults. Preventive Medicine Reports. 2019; 14: 100829. PMid: 30949424. https: //doi.org/10.1016/j.pmedr.2019.100829

[11] Pelletier DL, Olson CM, Frongillo EA. Food insecurity, hunger, and undernutrition. Present Knowledge in Nutrition. 2012:1165-1181. [Published online first: 18 June 2012]. https://doi . org/10.100 2/9781119946045.ch68

[12] Hamrick KS, Andrews M. SNAP participants' eating patterns over the benefit month: A time use perspective. PLoS One. 2016; 11(7): e0158422. PMid: 27410962. https://doi.org/10.1371/jour nal.pone. 0158422

[13] Amin SA, Yon BA, Taylor JC, et al. Impact of the national school lunch program on fruit and vegetable selection in northeastern elementary schoolchildren, 2012-2013. Public Health Rep. 2015; 130(5): 453-457. PMid: 26327723. https ://doi.org/10.1177/003335 491513000508

[14] Hartline-Grafton H, Dean O. The impact of poverty, food insecurity, and poor nutrition on health and well-being. Washington, DC: Food 
Research \& Action Center; December 2017.

[15] Kabalo BY, Gebreyesus SH, Loha E, et al. Performance of an adapted household food insecurity access scale in measuring seasonality in household food insecurity in rural Ethiopia: A cohort analysis. BMC Nutrition. 2019; 5(1): 54. PMid: 32153967. https : //doi.org/10.1186/s40795-019-0323-6

[16] Oh SY, Hong MJ. Food insecurity is associated with dietary intake and body size of Korean children from low-income families in urban areas. European Journal of Clinical Nutrition. 2003; 57(12): 1598604. PMid: 14647225.https://doi.org/10.1038/sj.ejcn. 16 01877

[17] Academy of Nutrition and Dietetics Foundation. Prioritizing Food Security Solutions. Available from: https: //eatrightfoundation.org/why-it-matters/public-edu cation/food-security-solutions/?fbclid=IwAR1kWe08x UTARpDkrsCUOPiql_K_UowE15mKgn7mqGcfVMaWAjizx_Ou3yI

[18] Jimenez EY, Piltch E, Knoblock-Hahn A, et al. Development and pilot testing of the prioritizing food security solutions toolkit. Journal of the Academy of Nutrition and Dietetics. 2019; 119(10): 1738-
1746. PMid: 31561812. https://doi.org/10.1016/j.jand.2 019.07 .023

[19] United States Department of Agriculture. FNS Responds to COVID19. Available from: https://www.fns.usda.gov/coronavirus

[20] United States Department of Agriculture. Healthy Hunger-Free Kids Act. Available from: https://www.fns.usda.gov/cn/health $\mathrm{y}$-hunger-free-kids-act

[21] United Nations Children's Fund USA. What Is Ready-to-Use Therapeutic Food? Available from: https://www. unicefusa.org/st ories/what-ready-use-therapeutic-food/32481

[22] Schoonees A, Lombard MJ, Musekiwa A, et al. Ready-to-use therapeutic food (RUTF) for home-based nutritional rehabilitation of severe acute malnutrition in children from six months to five years of age. Cochrane Database of Systematic Reviews. 2019; 5. PMid: 31090070. https://doi.org/10.1002/14651858.CD0 09000.pub3

[23] Internal Revenue Service. Economic Impact Payments. Available from: https://www.irs.gov/coronavirus/economic-impac t-payments 